\title{
Re-reading 1 Corinthians 6:12-20 in the context of Nigerian Pentecostals' theology of sex
}

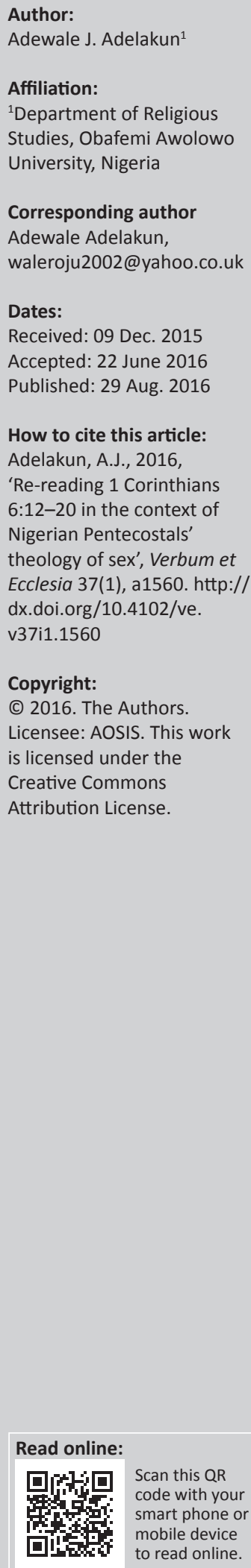

This article examines Paul's teachings on sexuality in 1 Corinthians 6:12-20 and the relationship between those teachings and the prevalent sexual practices in Corinth. It is argued that Paul's quest for robust spirituality among the Christians in Corinth informed his injunctions against certain sexual acts which were permitted in the then Greco-Roman world. The text is also read in the context of Nigerian Pentecostals' theology of sex. The conclusion of this article is that Nigerian Pentecostals' theology of sex is diluted in the sense that it emerges from both the African cultural belief and biblical injunctions, especially Paul's teaching about sex in 1 Corinthians 6:12-20.

Intradisciplinary and/or interdisciplinary implications: The confusion and controversy this kind of theology generates will continue to be a major concern for scholars in the fields of biblical interpretation, theology, sociology and other related disciplines.

\section{Introduction}

The contemporary debate on sexuality in Africa is intrinsically premised on cultural beliefs which provide the impetus for understanding sexuality in the continent. This is true in nations like Nigeria, where traditional beliefs play important role in defining and shaping human's sexual behaviour and orientation. A sexual act is considered appropriate if it is culturally right. ${ }^{1}$ The argument of this article is that cultural belief is not a strong premise upon which understanding of sexuality can be built. Spirituality is proposed as the alternative premise to culture for Christians. This notion is taken from the re-interpretation of 1 Corinthians 6:12-20. The interpretation of the text implies that Paul's teaching on sex is aimed at promoting and enhancing the spirituality of Christians in Corinth. Walter Principe's definition of spirituality as 'the way people live and understand their religious ideal in sensitivity to the realm of the spirit' is adopted (Principe 2000:48). For Christians, the 'realm of the spirit' will be the Holy Spirit or Spirit of God through Jesus Christ.

It is argued in this article that Paul did not want Corinthian Christians to indulge in the permissive culture of the Greco-Roman world but they were to do what would enhance their relationship with Jesus who had bought them with his blood. The contextualisation of 1 Corinthians 6:12-20 shows that Nigerian Pentecostals do not reject traditional cultural belief about sex outright but dilute it with Paul's teachings to formulate their theology of sex. The teachings of three leading Nigerian Pentecostal leaders on sexuality are examined. They are W.F. Kumuyi of Deeper Christian Life Ministries (DCLM), Daniel Olukoya of Mountain of Fire and Miracles Ministries (MFM) and Olusola Areogun of Life Oasis International Church (LOIC). DCLM and MFM have their headquarters in Lagos, while LOIC's headquarters is in Osogbo. The three churches have branches in Nigeria and abroad.

\section{Corinth and its prevalent sexual permissiveness}

Corinth was a city of Greece which was located at the west end of the Isthmus between central Greece and the Peloponnesus. The city was in control of trade routes between northern Greece and the Peloponnese and across the isthmus. It was a flourishing centre of trade, as well as of industry, particularly ceramics. The city was dominated by the Acrocorinth (566 m), a steep, flattopped rock surmounted by the acropolis. In the ancient time, the acropolis contained a temple of Aphrodite, goddess of love, whose service gave rise to the city's proverbial immorality, notorious already by the time of Aristophanes (Harrop 1980:313). Archaeologists have discovered stone implements and pottery vessels which attest to the fact that there was life in Corinth as far back as the Neolithic period. The tools of metal discovered show the transition to the Early Bronze Age,

1.In Nigeria the prominent argument against same-sex relationships is that it is alien to Nigerian cultural and religious beliefs. 
ca. 3000 BCE. About 2000 BCE, the city seemed to have been devastated, and then at the beginning of the first millennium BCE it was occupied by the Dorian Greeks (Finegan 1962:682). In the 7th century Cypselus made himself the tyrant of the city and was succeeded by his son Periander (ca. 625-ca. 583 $\mathrm{BCE}$ ), under whom Corinth reached great power and prosperity. It was known for pottery and bronze work, and its products were carried far and wide by extensive shipping (Finegan 1962:682).

The city was destroyed by the Roman general Lucius Mummius in 146 BCE. The city lay ruined for about a 100 years (Lenski 1961:10). It was rebuilt as a Roman colony in accordance with a decree by Julius Caesar in 44 BCE not long before his death. The city was formerly known as Ephyra (Efura), meaning 'lookout' or 'guard', but now in honour of its new founder was called Colonia Laus Julia Corinthiensis, a name which has been found in an inscription at Corinth (Finegan 1962:682). The new city quickly rose to a prominent place among cities in the Roman Empire. It was admirably adapted for shipping and for trade. The mixed population included the Jews, the Greeks and the Romans. Augustus made the city the capital of the new province of Achaia, detached from Macedonia and ruled by a separate proconsular governor (Harrop 1980:313). The colonists consisted of freedmen from Italy who were later joined by the Greeks, Orientals and many Jews, among others.

The immorality of the old Corinth was so intense that Aristophanes ( $c a .450-385$ BCE) coined the verb korinthiazo which means 'to corinthianise', that is, to fornicate (Callaway 1960:381). C.K. Barrett also argues in support of this assertion that the old Corinth was the immoral one while the immorality of the new Corinth, that is, the recipient of Paul's letter, was not as keen as the old Corinth destroyed by the Romans. He observes that, 'In Paul's day, Corinth was probably little better and little worse than any other great sea port and commercial centre of the ages' (Barrett 1971:3). In other words, the new Corinth, as a sea port, was permissive of sexual immorality, just like any other sea port, but not as bad as the old Corinth.

Corinth's permissive sexual tendency can be attributed to three factors: economic, religious and philosophical. The economic prosperity of the city, occasioned by its location, brought a number of people to the city. The temple in the city, which services included male and female prostitution, made sexual gratification available for the inhabitants of the city. According to Keener, many Greek philosophers reasoned that fornication was fine as long as it did not control the person. They 'excused relieving their sexual appetites with prostitutes or by publicly stimulating themselves, explaining that they were in complete control of their own emotions' (Keener 1993:472). Many young people in Corinth visited brothels to have sex with prostitutes and slaves.

Acts 18 records that Paul went to Corinth from Athens to preach during his second missionary journey and spent 18 months there. Paul's missionary activities were successful in
Corinth. Engels suggests three important reasons why Paul stayed so long and recorded success in Corinth. Firstly, Corinth was a major destination for traders, travellers, and tourists in the eastern Mediterranean. Thus, it was an ideal location from which to spread word of a new religion or philosophy. Secondly, because of its economic prosperity, the city provided Paul an opportunity to work and earn his living without depending on anybody. There was probably a good market for tents in Corinth due to the influx of visitors who came to participate in the spring game. The third reason is the Isthmian Games which began in $581 \mathrm{BCE}$, at the Temple of Poseidon. The 51 C.E. edition was celebrated when Paul was in the city. It would be an opportunity for him to encounter many spectators and participants who could take the word of the new faith to many distant places (Engels 1990:112).

\section{Content, context and exegesis of 1 Corinthians 6:12-20}

1 Corinthians 6:12-20 introduces us to the 'Corinthians slogans' and Paul's responses to the slogans. Certain statements or expressions are believed to have emanated from the Corinthians to which Paul responded. Sometimes, it may be difficult to determine when Paul expressed himself and when he was quoting someone partly because of lack of direct quotation (Burk 2008:100-121). However, a critical study of 1 Corinthians reveals that the letter consists of statements and phrases which emanated from the Corinthians. Which statements belong to Paul or the Corinthians? There is no consensus among scholars on this. Nevertheless, Denny Burk has proposed a guide to identify the slogans and Paul's words (Burk 2008:100-102). Burk is able to identify slogans in $6: 12,13$ and 18 by establishing the fact that Paul uses diatribe form in his epistle to the Corinthians.

Burk is of the view that Paul was influenced by the GrecoRoman use of diatribe which had the following elements: a vivid dialogue mode, imaginary second-person interlocutors, objections or false conclusions, characteristic rejection

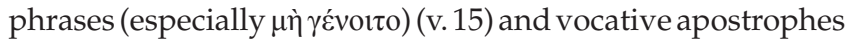
such as $\dot{\omega} \dot{\alpha} v \rho \omega \pi \varepsilon$. Some of the common features of diatribe genre in 1 Corinthians 6:12-20 include dialogue, using second-person plural and rhetorical questions. When the second person is used with a rhetorical question, it signifies the presence of the use of diatribe. In 6:12-20 one can identify the following features of diatribe form:

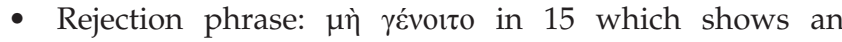
objection raised by Paul.

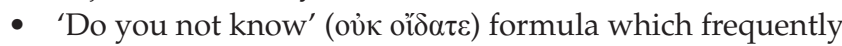

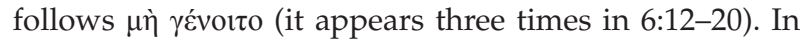

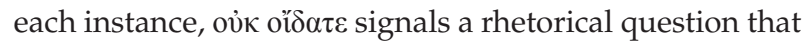
functions as a supporting statement for Paul's rejection of the interlocutor's false inference.

- There are 10 addresses in the second-person plural which imply a conspicuous use of diatribe.

- Dialogue between Paul and his interlocutor which may be real or imaginary, but in this case it is real because Paul 
is speaking to a real situation which makes the letter to be occasional. This is established more by the use of secondperson plural which obviously suits Paul's purpose of addressing a concrete situation that involves more than one person in the Corinthian community.

- There is always an objection from the Corinthians which precipitates Paul's rejection.

- The formula is Objection or the Corinthians slogan - Paul's rejection phrase - Paul's supporting statement. Burk identifies this pattern from the text (Burk 2008:100-105).

In 6:12 the objection from the Corinthians is 'All things are lawful for me', which Paul immediately rejected using adversative particle $\delta \grave{\varepsilon}$ (but), followed by Paul's supporting statement which is counter-assertion, 'not all things are profitable'.

Using this formula, it is observed that objection comes in the form of the Corinthian slogan, not in the form of a rhetorical question. Following the slogans, the rejection is implied by adversative particles such as $\dot{\alpha} \lambda \lambda \dot{\alpha}$ in $12, \delta \dot{\varepsilon}$ in 13 and $\delta \dot{\varepsilon}$ in 18 . Each of these particles is followed by various supporting statements, only one of which is introduced by the characteristic oúк oí $\delta \alpha \tau \varepsilon$. This suggests strongly that Paul used a special adaptation of the diatribe that substitutes Corinthian slogans for imaginary interlocutors in verses 12, 13 and 18. Other slogans in the text include 'Foods for the stomach and the stomach for foods', (v. 13); 'Every sin a person commits is outside the body', (v. 18). ${ }^{2}$

The Corinthians thought that they were free to do all things. Paul did not deny this but gave a restrainer: not all things

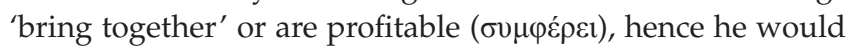
not let anything have authority over him (v. 12). The Corinthians would also say 'Foods for the stomach and the stomach for foods'. They probably meant that sex is for the body and the body is for sex. Paul's response is that the body belongs to the Lord. It is not meant for sexual immorality. In verse 13 Paul used the dative of advantage. Dative of advantage shows 'for' whose benefit something exists or is

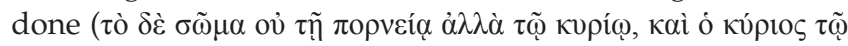
$\sigma \omega \mu \alpha \tau$ (and the body is not for immorality but for the Lord and the Lord for the body). This kind of dative is used in Luke 16:9 (MacDonald 2005:85).

Verse 14 points to the resurrection of the body in the last days, which is fully discussed in chapter 15 . In verse 15 Paul used rhetorical questions to disseminate new information about the physical bodies of believers. $\Sigma \tilde{\omega} \mu \alpha \tau \alpha$ (noun nominative neuter plural from $\sigma \tilde{\omega} \mu \alpha)$, translated 'bodies', refers to the physical body. It is the organ of human's activities (Arndt \& Gingrich 1957:806-807). In Paul's belief, Christians' bodies belong to Christ ( $\mu \varepsilon \dot{\lambda} \eta \mathrm{X} \rho \iota \sigma \tau \tilde{v})$. This is the reason why it is wrong for one to take (öpas from $\alpha i p \omega$, take away) the body of Christ to prostitute.

Prostitution was common as a religious rite in the ancient world. Evidence of cultic prostitution was first found among

2.For a fuller discussion on this phrase see Smith (2008). the Babylonians. Herodotus recounts that once in her life every Babylonian woman had to 'sacrifice' herself to the goddess Mylitta by giving her body to a stranger in the temple precincts (Reisser 1982:497). In the Greek world cultic prostitution gained acceptance primarily in the great sanctuaries of Corinth and Athens. One of the reasons for the wide spread of prostitution (both cultic and secular) and sexual immorality in Ancient Greece was the citizen law of 451 BC which did not allow any inhabitants of Athens to have citizenship if their parents were not both Athenians. This made non-Athenian men and women to be economically disadvantaged. Many of them had to work more and more as prostitutes to survive. Thus began the professional class of hetaerae (Reisser 1982:497-498). The availability of slaves used as sex objects also contributed to the widespread of prostitution in Corinth. Slaves were regarded as bodies in the Greco-Roman world. They were designated as bodies in official documents like wills and listing of property. This implies that slaves were '... vulnerable to physical control, coercion, and abuse in settings as public as the auction block and as private as the bedroom' (Glancy 2002:9). Slaves were subjected to sexual abuse. They were used as sex objects by their slaveholders. Glancy (2002:10) argues that treating slaves as nobody but property was a common practice which was not considered as immoral. Even though the first-century church had slaves and slaveholders in its membership, the church did not condemn the practice.

Another reason for the widespread of prostitution among the ancient Greeks is that most women were not educated and were thus regarded as oikourema, a chattel used for looking after the house and for bearing legitimate children. The married men were free to sleep with slaves and also have concubines for the daily care of their bodies. This, on the other hand, encouraged married women to have sexual affairs with the slaves and to indulge in lesbian love (Reisser 498).

Paul rejected the notion of going to prostitutes (i.e. taking the

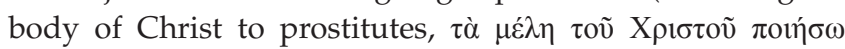

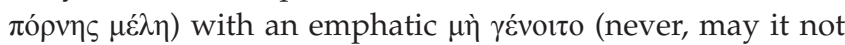

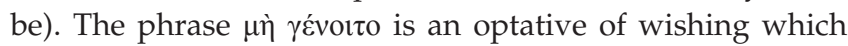
strongly deprecates something suggested by a previous question or assertion. Fourteen of the fifteen New Testament instances are in Paul's writings, and in 12 of these it expresses the apostle's abhorrence of an inference which he feared might be (falsely) drawn from his argument (Burton 1978:49). In addition, he also appealed to the Old Testament to strengthen his point that having sexual intercourse with a prostitute contravenes the original intent of God for marriage which requires the husband to have sexual union with his wife (Gn 2:24). Paul cited the LXX which adds the words oi

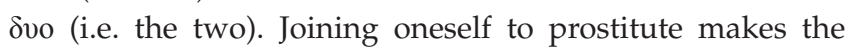
person to be one with the prostitute the same way joining oneself with the Lord makes the person to be one in spirit with the Lord (16-17). As Garland (2003) has rightly observed:

Sexual union creates an enduring bond. The verb ко $\lambda \lambda \alpha \alpha_{0} \mu \alpha$ (kollaomai) in v. 16 implies that the man and the prostitute are 
wedded together even if there are no wedding vows. The man who has sexual intercourse with a prostitute and the prostitute may view their union as only a temporary liaison which will give the man sexual release and the prostitute a living. However, it is more entangling than that; neither is free from the other after the sexual intercourse. (p. 234)

Another important message from the text is the assumption of the new meaning for the body. It is not a mere outer shell or container that the soul will discard at death. The Christian's body is destined for resurrection. The importance of the body, contrary to irrelevance attached to it by the Corinthians, occupies the rest of chapter 6 . Since the body is not relevant to one's salvation, argued the Corinthians, sexual immorality has no costly consequence because it is a sin against one's body. Paul admonished them to flee (

Interpreting verse 18, scholars such as Jay E. Smith, among others, have applied various means to get to the root of the verse. While most scholars regard the verse as containing a Corinthian slogan, some reject the view outright. ${ }^{3}$ Jay Smith notes astutely that theological and philosophical arguments have been proffered for the interpretation of this verse (Smith 2010:68-69). Theologically, the Imago Dei and the Trinitarian nature of God have been used to isolate sexual immorality as a unique sin. Theological argument denies that the verse contains any Corinthian slogans. Philosophically, Augustine's theory of 'evil corrupts everything' has been used to also deny the verse as containing a slogan. Augustine wrote that corruption cannot consume the good without also consuming the thing (the being or person) itself. When this is applied to verse 18 , it is believed that sexual immorality corrupts not just the body but 'consumes the whole person, that is, destroys a person's mind, conscience and active moral-discerning ability and thus destroys the capacity for knowing and loving God' (Smith 2010:70). Garland (2003) further presents the objections raised against interpreting verse $18 \mathrm{~b}$ as a Corinthian slogan thus:

The statement 'every sin that a man commits' is a notorious crux. Many have tried to resolve the problem by turning it into 'a mere Corinthian quirk' and dismiss it as another of their bizarre slogans. This view assumes that the Corinthians' fallacious anthropology lies behind a claim that what is merely physical, such as sexual activity, is morally irrelevant because it does not touch and cannot harm the inner citadel of the soul. This view is to be rejected because Paul includes no marker to signal the presence of a quotation. The $\delta \dot{\varepsilon}($ de), unlike $\dot{\alpha} \lambda \lambda \dot{\alpha}$ (alla) in 6:12, does not function as a contrastive particle but expresses an exception: 'Every sin a man commits is outside the body with the exception of the immoral man who sins against his own body'. (p. 236)

Fee (1987) understands $18 \mathrm{~b}$ as a theological point made by Paul. He writes:

With a double asyndeton Paul says (literally): 'Flee from sexual immorality. Every sin, whatever it is a man commits, is outside the body, but he who commits sexual immorality sins against his

3.Smith (2010), presents a detailed argument to establish the fact that 1 Corinthians $6: 18 \mathrm{~b}$ is a slogan. He interprets the phrase 'every sin that a man commits is outside $6: 18 \mathrm{~b}$ is a slogan. He interprets the phrase 'every sin that a man commits is outside
the body' as slogan, while the remaining part of the verse contains Paul's total the body' as slogan, whil
rejection of the slogan. own body'. Paul's concern is with the final clause, that in sexual immorality a man sins against his own body - which turns out to be his own but not his own .... In fornication with a prostitute a man removes his body (which is a temple of the Spirit, purchased by God and destined for resurrection) from union with Christ and makes it a member of her body, thereby putting it under her 'mystery' (v. 12b; cf. 7:4). Every other sin is apart from (i.e., not 'in') the body in this singular sense. (pp. 251-252)

As convincing as Garland's and Fee's arguments seem Buck rightly knocks them out with the fact that the excessive use of de upon which their interpretation of the verse is built is not found in any Greek grammar book. It originated from Fee's view. It is safer to hold the view that verse $18 \mathrm{~b}$ is a Corinthian slogan because of its hermeneutical implications. Firstly, the idea that sexual sin is against one's own body is not found elsewhere in the Bible. Secondly, holding that 'sexual sin is against one's own body' is contrary to Paul's view of the ownership of the body. The body belongs to Jesus Christ. The Corinthians who held the view did not understand this. They believed that their bodies belonged to them. However, Paul's concept of the body is that it belongs to Jesus and it is the temple of the Holy Spirit. It should be used to glorify God. This view is in line with Paul's teaching in Romans 12.

Paul concluded his admonition with the last 'do you not know' formula. He gave a theological justification for his injunction in verse 18a: The Christians' bodies are the Holy Spirit's sanctuary who lives in them. Hence, they are not their own. Fee rightly observes that Paul has taken the imagery which belongs to the church as a whole and applied it to individuals when he asserts that their body is the temple of the Holy Spirit. As noted above, Corinth was famous for its magnificent temple worship and sea port where all sorts of sexual immorality were practised. The Corinthian Christians were to stand in opposition to that temple.

Considering Paul's admonition in the light of the relationship between slaves and slaveholders in the church and what could have been the implication of Paul's teaching for the slaves, Glancy is of the view that it would be difficult for slaves to avoid $\pi$ opveía as stipulated by Paul. Paul had enjoined the Corinthian church to excommunicate members who were guilty of $\pi$ opveía (1 Cor 5:11). Glancy (2002:50) believes that enslaved prostitutes, who were at the mercy of their masters and were meant to satisfy their sexual urge, would find it difficult to retain their membership in such a situation. In other words, if Paul's admonition is to be followed by all and sundry, slaves would not be allowed to be members of the first-century church. Since slaves were members of the early church, Paul's admonition was probably not applicable to them. Logically, Glancy's argument is sound and reasonable. However, Glancy does not recognise the fact that no slave would be in the church without their masters. Slaveholders who became Christians in the NT did so with all their household, which included their slaves. If Paul's injunctions were to be obeyed by slaveholders, nobody would expect the slaves to be exempted from them no matter how precarious their status was. 


\section{Implications of 1 Corinthians 6:9-20 and spirituality of the Corinthians}

Even though the word 'spirituality' does not appear in 1 Corinthians 6:9-20, its message resonates throughout the whole pericopes. Going by the definition of spirituality by Principe, Paul's injunctions on sex in verses 12-20 have one focus: helping the Corinthians to 'live and understand their religious ideal in sensitivity to the realm of the Spirit'. The rhetorical question 'Do you not know ...?' signifies that Paul expected the Corinthian Christians to understand their spirituality and what it entailed. He reminded them of the fact that their physical body was not ordinary but the temple of the Holy Spirit. The Christians were expected to be God's representatives in a culture that was permissive and full of immoral acts.

Sex in Paul's view goes beyond having fun. It connotes a union between man and woman. Sleeping with a prostitute indicates joining (as in marriage) oneself together with the prostitute. Having sex is not an ordinary activity for Christians who have been joined together with Christ and thus it is forbidden to have sex outside marriage. Believers are thus enjoined to flee fornication.

In addition, the belief that 'God dwells in his people' was foreign to the Jews whose temple was in Jerusalem at the time Paul wrote the letter to the Corinthians. The Hebrew Bible states that God dwells with his people and not in their bodies as Paul claimed. This concept places the physical body in a high esteem contrary to the belief of some Corinthians and Gnostics that any sin against the body has no effect since the body is going to be destroyed by God someday. In contrast, Paul's view is that sexual immorality destroys the body which is God's temple and God, in turn, will destroy anybody who destroys his temple. Having sex with prostitute is tantamount to destroying God's temple. It should be unthinkable for believers whose physical bodies have become Christ's. The implication of this is that unholy sex (sexual immorality) and spirituality are incompatible with the Christian faith even though it was culturally permitted in Corinth.

Moreover, having sex with prostitutes (whether temple prostitutes or commercial ones) was not frowned at by the Corinthian society. The Christians in Corinth believed (wrongly) that they could have sexual intercourse with prostitutes since it was a common practice in their society. It is, however, clear from the text that Paul did not want the Corinthian Christians to indulge in the permissiveness of the culture of their society. His reason was based on the understanding that 'the body is not meant for immorality but for the Lord and the Lord for the body'. Even though the Corinthians might think that they were free to go into prostitution since it was permitted (lawful) in the society, Paul's injunction is that the Lord, not culture or philosophy, should dictate how Christians use their physical bodies. In other words, culture should not dictate what Christians do but spirituality. This does not suggest that Paul condemned culture outright. At least, his theology of sex contained some Jewish and Hebrew Bible flavour.

\section{Nigerian Pentecostals' theology of sex}

Nigerian Pentecostals' theology of sex is premised on a conservative understanding of sexuality and it is aimed at promoting sexual purity among Pentecostals. This puts restriction on members who are to be guided by rules and regulations as stipulated by their churches. This is highlighted by the selected churches: DCLM, MFM and LOIC.

\section{Deeper Christian Life Ministries}

The theology of sex in DCLM is built on the conservative teachings of Pastor W.F. Kumuyi, the founder and General Superintendent of DCLM. The church is popularly known as holiness church because of its emphasis on holiness. Thus, sexual purity and chastity form the basis of the DCLF's theology of sex. The church teaches that God makes no provision in his word for young people to have friends for fleshly pleasure. Secret love among youth brings serious curse. Lust yields a curse (Kumuyi 1983:101-102). For this reason, the church does not encourage girlfriend or boyfriend relationship. A boyfriend or girlfriend is referred to in Yoruba as Ore a bani d'ese, meaning a 'partner in committing sin'. It is regarded as an avenue to commit sexual immorality. It is also considered as a leeway for lust which is disastrous for youth. The church alleges that youths who are driven by lust can sometimes use church meetings as an opportunity to indulge in sinful habits (Kumuyi 1983:102). Consequently, young people are monitored and advised to run away from any forms of sexual sin. The church condemns fornication, premarital or extramarital sex, pornography, prostitution and sexual behaviours which the church believes are not congruent with the teachings of the Bible.

According to the teachings of DCLM, one of the reasons why youths fall into $\sin$ is because they cannot differentiate between love and lust. Youths are made to believe that love is from God while lust is from Satan. Love is shed in the Christian's heart by the Holy Ghost while the devil puts lust in people's hearts. While love makes one to be spiritual, lust makes one carnal. Love is commanded by God but he condemns lust. True love is good while lust is bad and evil (Kumuyi 2013). On this basis, any sexual relationship outside marriage is strongly denounced and sexual purity regarded as a harbinger of success, promotion and prosperity (Kumuyi 2013).

\section{Mountain of Fire and Miracles Ministries}

MFM's theology of sex is unique and peculiar due to the emphasis of the church on deliverance from evil powers. While Pentecostals are known for prosperity gospel, MFM goes beyond it to emphasise deliverance gospel which has 
been otherwise described as security gospel (Omotoye 2011). The security gospel informs the church's theology of sex. Apart from this, MFM attaches great importance to sex, which explains the reason why sex is explicitly discussed by the church founder, Daniel Olukoya. According to Olukoya, sex is sacred. It was created by God for humans' pleasure. However, anybody who gets involved in sex abnormally will suffer for it. Olukoya teaches emphatically that premarital sex or extramarital sex is a wide road to the grave. It is an opening through which demons possess people.

In line with the teaching of Paul in 1 Corinthians 6:12-20, MFM believes that sex is more than ordinary. It symbolises a bond between a man and a woman. For this reason, blessings and curses could be transferred from one person to another while having sexual intercourse. For example, if the man with whom a woman is having sex is accursed, MFM claims that all the curses of the man would be transferred to the woman and the woman's curses would also be transferred to the man. Such transfers of curses could lead to death, misfortune, bad luck, accident, delayed marriage and barrenness (Olukoya 2012:21). Olukoya (1999:14) observes, perhaps strangely, that women who are exceptionally beautiful moving around the streets looking for men who would sleep with them are not ordinary human beings. Such women are believed to come from the marine world and are possessed with demons. Any man who has sex with them toils with his destiny. It is also believed that having sex with a person from a polygamous home attracts demons into ones' life because polygamous family is considered as the breeding ground for all sorts of demons (Olukoya 1999:58-59).

On the other hand, sexual intercourse within the confines of marriage attracts God's blessing. Sex in this context is created for procreation and companionship. Husbands and wives who have sex in a normal way would be blessed. Oral sex is considered abnormal. It is an aberration and abomination. The penis according to Olukoya, is made to be inserted into the vagina and not into the mouth.

Treating sex from deliverance or security gospel's perspective, Olukoya admits that problems which arise from illicit sexual affairs are difficult to deal with through deliverance even though deliverance is the only solution to them. It is believed that girls that are promiscuous are possessed by demons which drive them crazy for sex (Olukoya 1999:58-59). Any man who sleeps with such girls would be infected with intractable problems. In his sermon titled 'Dancers at the Gate of Death', Olukoya (2008) narrates the story of a man who had sexual intercourse with the spirit of a dead girl which appeared to him as a human being. The man was infected with madness which could not be cured until the man was brought to MFM. Other problems could be easily solved through fasting and prayer but problems from sex require aggressive and fervent prayers which MFM is known for.

\section{Life Oasis International Church}

The theology of sex in LOIC is based on the teachings of the founder and co-founder of the church, Olusola and Oyenike Areogun. Olusola Areogun, just like his wife, Oyenike, believes that sexual sin is an obstacle to fulfilling God's purpose for one's life. Sex is good and is created for those who are married and should not be practised outside marriage. Areogun teaches that Christians are not pure until they are sexually pure. Hence, he urges sexual purity. Sex is also likened to food. Olusola Areogun, commenting on 1 Corinthians 6:13, observes (wrongly) that if one cannot control one's appetite for food one would not be able to control one's appetite for sex (Areogun 2012:19).

Moreover, sex is linked with cultic power. Areogun (2012) is of the view that:

a witchcraft spirit is not only when a woman is flying in the night, one of the major works of witchcraft in the world today is the use of the body to pervert the authority of people in different ways. That is why we have a nation that is not progressing in spite of its great potentials. The spirit of witchcraft has captivated so many things. It is a perversion of authority. (p. 21)

One of the reasons why Christians should pursue sexual purity is that their bodies serve as a carrier that takes anointing to wherever it wants to go; 'the anointing does not rest on your spirit; the anointing rests on your body and it transmits through your body' (Areogun 2012:23). Women are believed to be the vessels the devil uses to trap men. According to Olusola Areogun (2012:19), some women have been assigned by Satan to entice men and they employ black magic to manipulate men and destroy their destinies. Believers are enjoined to shun anything that can lead them into sexual sin. Pornography, immoral thoughts and evil company are to be forsaken. Instead, believers should determine to be sexually pure and confess positive things into their lives in order to be free from sexual immorality.

\section{African culture and Nigerian Pentecostals' theology of sex}

In developing their theology of sex, Nigerian Pentecostals find waiting hands in the African traditional culture which has some beliefs and practices similar to the teachings of Bible. Hence, Nigerian Pentecostals' theology can be taken as an amalgamation of the African culture and biblical teachings, especially Paul's teaching in 1 Corinthians 6:9-20. This does not suggest that the two cultures agree hand-in-hand on all sexual issues. There are points of divergence in the two cultures, but these are beyond the focus of this article.

On the level of similarity, both Pentecostals and African culture uphold chastity. Premarital or extramarital affairs are frowned at and condemned. In Yoruba culture, women are expected to be faithful to their husbands even when their husbands are having extramarital affairs. However, Pentecostals consider extramarital affairs and sex outside marriage as sources of problems in life. Members are 
encouraged to be faithful to their spouses. Kumuyi, the General Superintendent of The DCLM, affirms that women who are married to husbands who are unbelievers should be faithful to them. This, according to him, can win such a person for Christ (Kumuyi online).

The treatment of women in the theology of sex of Pentecostals in Nigeria raises some serious concerns. Women, more than often, are regarded as sources of temptation to men. They are portrayed as sources through which demons are transferred to men. This is informed by Yoruba belief that some women are from the spirit world, especially if they are beautiful. In traditional Yoruba culture, for instance, girls that are emere or mummy water in South-eastern Nigeria are believed to be extraordinarily beautiful and anybody who sleeps with them would be possessed by an evil spirit (Abey online). This, no doubt, forms the basis of MFM and LOIC teachings on how women are used by the devil to destroy men's destinies. Demonisation of women should not be encouraged among Christians. Apart from this, the view that Satan uses women to destroy people's destinies is inconsistent with Paul's injunction in 1 Corinthians 6:12-20. Both men and women are commanded by Paul to run away from sexual immorality. Moreover, putting the burden of proof on women in issues relating to sexual immorality, which is common in Africa, is not biblical. Men are rarely punished for adultery. Women are always the culprits (Alaba 2004:6). Men are free to marry more than one wife while women are supposed to be faithful to their unfaithful husbands.

\section{Conclusion}

To what extent should people allow their culture to shape and define their sexuality? Africans are fond of appealing to culture when it comes to sexual issues. At the heat of the debate on whether to legalise same-sex relationships in Nigeria, members of the National Assembly at various points cited Nigerian culture as the main reason why it should not be legalised. So, culture is a powerful tool in decision-making on sexual issues. But is it right to appeal to culture in sexual issues? Culture is relative and dynamic. Culture differs from one place to another. Yoruba culture is different from Igbo culture even though both are within the same country. It is not strange that Western culture is eroding African culture, indicating that the latter is not static and can be easily influenced while the former receives little or no influence from the latter. On the other hand, spirituality which emphasises relationship with a supreme being is more reliable than culture. It allows individuals to express their sexuality in accordance with their relationship with God. In other words, it is whatever or whoever humans hold as the ultimate that should define and shape their understanding of sexuality. For Christians, it is God as revealed in the scriptures.

It is to be noted that Pentecostals' theology of sex is not a well-defined theology. Pentecostals do not emphasise doctrinal beliefs like mainline Protestant churches. Pentecostals' theology of sex can mainly be found in the teachings and sermons of their leaders whose' injunctions are religiously obeyed and regarded as the word of God. 1 Corinthians 6:12-20 plays an important role in the theology of sex of Nigerian Pentecostals. The text forms the basis for the formulation of the theology of sex among Nigerian Pentecostals as the text is often quoted and interpreted even though the interpretation is sometimes awkward. In addition to the text, it has also been pointed out that some traditional cultural beliefs are alluded to in the formulation of Pentecostals' theology of sex. As pointed out above, cultural beliefs should not be used as a basis for Christian theology. Doing this leads to a diffused theology as can be seen from the examples of the churches cited above. Spirituality needs to be considered in any formulation of theology of sex. The diluted theology of sex of Nigerian Pentecostals will continue to attract scholarly interests from not only theologians, but also sociologists, anthropologists and feminists who are interested in the dynamic nature of culture.

\section{Acknowledgements Competing interests}

The author declares that he has no financial or personal relationships which may have inappropriately influenced him in writing this article.

\section{References}

Abey, U., 'The Yoruba Concept of Abiku and Emere in Yorubaland', viewed 19 February 2015, from http://ekimogundescendant.org/index.php?option=com content\& view=article\&id=114:the-yoruba-concept-of-abiku-and-emere-in-yorubaland \&ca tid=34:articles\& $\&$ temid $=53$

Alaba, O., 2004, Understanding sexuality in the Yoruba Culture, African Regional Sexuality Resource Centre, Lagos.

Areogun, O., 2012, Sexual purity, Abundant Life House, Osogbo.

Arndt, W.F. \& Gingrich, F.W., 1957, A Greek-English Lexicon of the NT and other early Christian Literature, University of Chicago Press, Chicago, IL.

Barrett, C.K., 1971, A commentary on the first epistle to the Corinthians, Adam \& Charles Black, London.

Burk, D., 2008, 'Discerning Corinthian slogan through Paul's use of the diatribe in 1 Corinthians 6: 12-20', BBR 18(1), 100-121.

Burton, E.D.W., 1978, Syntax of the moods and tenses in New Testament Greek, Kregel Publications, Grand Rapids, MI.

Callaway, J.A., 1960, 'Corinth', Review and Expositor LVII (4), 381. http://dx.doi. org/10.1177/003463736005700402

Engels, D., 1990, Roman Corinth: An alternative model for the classical city, University of Chicago Press, Chicago, IL.

Fee, G.D., 1987, The first epistle to the Corinthians, William B. Eerdmans, Grand Rapids, MI.

Finegan, J., 1962, 'Corinth', in G.A. Buttrick (ed.), The Interpreter's Dictionary of the Bible, p. 682, Abingdon Press, New York.

Garland, D.E., 2003, 1 Corinthians, Baker Academic, Grand Rapids, MI.

Glancy, J.A., 2002, Slavery in Early Christianity, Oxford University Press, Oxford.

Harrop, J.H., 1980, 'Corinth', in D. Wood (ed.), The Illustrated Bible Dictionary, Part One, p. 313, Inter-Varsity Press, Leicester.

Keener, C.S., 1993, IVP Bible background commentary: New Testament, InterVarsity Press, Downers Grove, IL.

Kumuyi, W.F., 'Love without lust', viewed 31 March 2013, from www.deeperlifeonline.org Kumuyi, W.F., 1983, Complete Bible study series, Life Press, Lagos.

Kumuyi, W.F., 2013, 'The Christian wife and her unbelieving husband', viewed 31 March 2013, from www.deeperlifeonline.org

Kumuyi, W.F., 'Passing the test of purity', viewed 31 March 2013, from www. deeperlifeonline.org

Lenski, R.C.H., 1961, The interpretation of St. Paul's first and second epistles to the Corinthians, Augsburg, Minneapolis, MN.

MacDonald, W.G., 2005, Greek enchiridion: A concise handbook of grammar for translation and exegesis, Hendrickson Publishers, Peabody, MA. 
Olukoya, D.K., 1999, Power against Marine spirits, The Battle Cry Christian Ministries, Lagos.

Olukoya, D.K., 2008, Dancers at the gate of death, Sunday Worship Service Message.

Olukoya, D.K., 2012, 100 Reasons why sex must wait until marriage, Mountain of Fire and Miracles Ministries, Lagos.

Omotoye, R.W., 2011, 'Pentecostalism and the Yoruba world view: The case of mountain of fire and miracles ministries, Nigeria', The International Journal of Religion and Spirituality in Society 2, 191.
Principe, W., 2000, 'Toward defining spirituality', in K. Collins (ed.), Exploring Christian spirituality, an ecumenical reader, p. 48, Baker Academic, Grand Rapids, MI.

Reisser, H., 1982, 'ropveúw', in C. Brown (ed.), The New international dictionary of New Testament theology, p. 497, The Zondervan Corporation, Grand Rapids, MI.

Smith, J.E., 2008, 'The roots of a "Libertine" Slogan in 1 Corinthians 6: 18', Journal of Theological Studies 59, pt.1, 63-95. http://dx.doi.org/10.1093/jts/flm141

Smith, J.E., 2010, 'Slogans in 1 Corinthians', BSAC 167(665), 71. 